\title{
AKTSAR
}

ISSN 2622-5255 (online)

Volume 2 Nomor 2, Desember 2019, Halaman 265-282

ISSN 2622-2345 (cetak)

\section{Analisis Harga Saham Ditinjau dari Rasio Keuangan Perusahaan yang Listing di Jakarta Islamic Index (JII) Periode 2015-2017}

\author{
Bayu Tri Cahya \\ Institut Agama Islam Negeri Kudus \\ cahyab380@gmail.com \\ Eri Vitriani \\ Institut Agama Islam Negeri Kudus \\ vitriyanieri@gmail.com \\ Asih Andriani \\ Universitas Islam Negeri Sumatera Utara \\ asihandriani100@gmail.com
}

\begin{abstract}
This study aims to determine the Return on Asset (ROA), Current Ratio (CR), Debt to Equity Ratio (DER), Inventory Turn Over (ITO) on stock price in companies registered in the Jakarta Islamic Index in 2015-2017. The approach used in this study is a quantitative approach. The data in this study are secondary data. The data obtained from the site www.idx.go.id and the website of each company. The sample determination technique uses purposive sampling technique and data analysis using multiple regression analysis. The findings show that Return on Asset (ROA) affect stock price while Current Ratio (CR), Debt to Equity Ratio (DER), dan Inventory Turn Over (ITO) have no effect on the stock price.
\end{abstract}

Keywords: Stock Price; Financial Ratio; Jakarta Islamic Index 


\begin{abstract}
ABSTRAK
Penelitian ini bertujuan untuk mengetahui pengaruh Return on Asset (ROA), Current Ratio (CR), Debt to Equity Ratio (DER), dan Inventory Turn Over (ITO) terhadap harga saham perusahaan yang listing di Jakarta Islamic Index periode 2015-2017. Pendekatan yang digunakan dalam penelitian ini adalah pendekatan kuantitatif. Data dalam penelitian ini merupakan data sekunder. Data diperoleh dari laman www.idx.go.id dan web masing-masing perusahaan. Teknik penentuan sampel menggunakan teknik purposive sampling dan analisis data menggunakan analisis regresi linier berganda. Hasil temuan menunjukkan bahwa Return on Asset (ROA) berpengaruh terhadap harga saham sedangkan Current Ratio (CR), Debt to Equity Ratio (DER), dan Inventory Turn Over (ITO) tidak berpengaruh terhadap harga saham.
\end{abstract}

Kata kunci: Harga saham; Rasio keuangan; Jakarta Islamic Index

\title{
PENDAHULUAN
}

Investasi pada hakikatnya merupakan penempatan sejumlah dana pada saat ini dengan harapan untuk memperoleh keuntungan di masa mendatang. Umumnya investasi dibedakan menjadi dua, yaitu: investasi pada aset-aset riil (real assets) dan investasi pada aset-aset finansial (financial assets). Investasi pada aset-aset riil dapat berbentuk pembelian aset produktif, pendirian pabrik, dan lainnya. Sedangkan, investasi pada aset-aset finansial dilakukan di pasar uang dan di pasar modal, misalnya berupasertifikat deposito, saham, obligasi, dan lainnya (Halim, 2005). Diantara instrumen pasar modal di atas yang paling popular adalah saham.

Saham merupakan surat berharga yang menunjukkan bukti kepemilikan individu maupun institusi dalam suatu perusahaan (Amanah, et al., 2014). Pembelian saham merupakan salah satu alternatif yang menarik bagi investor, karena ada dua return yang akan diharapkan. Pertama deviden, merupakan keuntungan yang dibagikan oleh manajemen terhadap pemegang saham. Kedua, capital gain, merupakan selisih antara harga pada saat jual dan beli saham (Deitiana, 2013).

Harga saham merupakan salah satu indikator keberhasilan pengelolaan perusahaan, jika harga saham suatu perusahaan selalu mengalami kenaikan, maka investor atau calon investor menilai bahwa perusahaan berhasil dalam mengelola usahanya. Kepercayaan investor atau calon investor sangat bermanfaat bagi emiten, karena semakin banyak orang yang percaya terhadap emiten maka keinginan untuk berinvestasi pada emiten semain kuat. Semakin banyak permintaan terhadap suatu saham maka dapat menaikan harga saham tersebut, jika harga saham yang tinggi dapat dipertahankan maka kepercayaan investor atau calon investor terhadap emiten juga semakin tinggi dan hal ini dapat menaikan nilai emiten. Sebaliknya, jika harga saham mengalami penurunan terus menerus berarti dapat menurunkan nilai emiten dimata investor atau calon investor (Zuliami, 2013). 
Harga saham selalu mengalami pergerakan yang fluktuatif setiap saat. Peningkatan maupun penurunan harga saham selain dipengaruhi oleh permintaan dan penawaran dari investor juga dipengaruhi oleh faktor yang lainnya, ada faktor internal dan ada pula faktor eksternal. Faktor eksternal yang mempengaruhi harga pasar seperti kondisi perekonomian, kebijakan pemerintah, inflasi, kondisi politik dan lain-lain. Faktor internal yang mempengaruhi harga saham seperti, keputusan manajemen, kebijakan internal manajemen dan kinerja perusahaan. Perusahaan tidak dapat mengendalikan faktor eksternal karena faktor tersebut terjadi di luar perusahaan. Namun perusahaan dapat mengendalikan faktor internal agar harga saham perusahaan tidak turun. Salah satu caranya adalah melalui kinerja perusahaan (Meythi, et al., 2011). Terjadinya perbaikan prestasi perusahaan (kinerja keuangan dan operasional perusahaan), biasanya diikuti dengan kenaikan harga saham di lantai bursa (Umam, 2013).

Salah satu cara yang sangat populer untuk mengetahui kinerja emiten adalah menganalisa rasio keuangan (Sulistyastuti, 2002). Analisis rasio keuangan merupakan alat utama dalam analisis keuangan, karena analisis ini dapat digunakan untuk menjawab berbagai pertanyaan tentang keadaan keuangan perusahaan (Muslich, 2003). Analisis rasio keuangan merupakan alternatif untuk menguji apakah informasi keuangan bermanfaat untuk melakukan klasifikasi atau prediksi terhadap harga saham. Dalam rasio keuangan terdapat empat rasio keuangan yaitu rasio profitabilitas, rasio likuiditas, rasio solvabilitas dan rasio aktivitas.

Rasio Profitabilitas merupakan rasio yang menggambarkan kemampuan perusahaan dalam menghasilkan laba dari sumber dana yang dimiliki. Rasio profitabilitas yang berkaitan dengan efisiensi perusahaan dalam menghasilkan laba yang digunakan dalam penelitian ini, yaitu Return on Assets (ROA). Return on Assets (ROA) merupakan rasio yang mengukur kemampuan perusahaan menghasilkan laba bersih berdasarkan tingkat aset tertentu. Semakin tinggi rasio ini maka semakin baik keadaan suatu perusahaan dan menunjukkan bahwa perusahaan semakin efektif dalam memanfaatkan aktiva untuk meghasilkan laba bersih setelah pajak. Hal ini selanjutnya akan meningkatkan daya tarik perusahaan kepada investor. Yang selanjutnya akan berdampak pada harga saham dari perusahaan tersebut di pasar modal juga semakin meningkat. Dengan kata lain, ROA akan berpengaruh terhadap harga saham (Zuliami, 2017).

Rasio likuiditas merupakan rasio yang menggambarkan kemampuan perusahaan dalam memenuhi kewajibannya yang akan jatuh tempo (Lasmi, 2017). Rasio likuiditas yang digunakan dalam penelitian ini yaitu, Current Ratio (CR). Current Ratio (CR) merupakan salah satu ukuran likuiditas yang bertujuan untuk mengukur kemampuan perusahaan untuk melunasi kewajiban jangka pendeknya dengan aktiva lancar yang dimilikinya. Semakin baik Current Ratio (CR) sebuah perusahaan maka akan semakin likuid perusahaan tersebut, sehingga dapat meningkatkan minat masyarakat untuk berinvestasi pada perusahaan tersebut. Hal ini akan berdampak positif pada harga saham (Deitiana, 2013).

Rasio solvabilitas merupakan rasio yang digunakan untuk mengukur seberapa besar kemampuan perusahaan memenuhi kewajiban finansial jangka panjangnya. Rasio solvabilitas yang digunakan dalam penelitian ini yaitu, Debt to Equity Ratio (DER). Debt to Equity Ratio (DER) merupakan rasio solvabilitas yang mengambarkan 
berapa besar hutang atau jangka panjang dibandingkan jumlah modal yang dimiliki perusahaan. Apabila DER perusahaan tinggi maka ada kemungkinan harga saham perusahaan akan rendah. Sebaliknya, apabila tingkat DER rendah maka membawa dampak meningkatkan harga saham di bursa (Raprayogha et al., 2017).

Rasio aktivitas merupakan rasio yang menggambarkan kemampuan serta efisiensi perusahaan dalam menghasilkan penjualan dengan mendayagunakan aktiva yang dimiliki. Rasio aktivitas yang digunakan dalam penelitian ini yaitu, Inventory Turnover (ITO). Inventory Turnover (ITO) adalah rasio aktivitas yang menunjukan tingkat perputaran persediaan selama satu tahun. ITO akan memberi informasi kepada investor tentang seberapa baik perusahaan mengelola aset perusahaan berupa persediaan (Setiyawan dan Pardiman, 2014). Sehingga, apabila ITO perusahaan baik maka hal tersebut akan membuat investor tertarik untuk membeli saham perusahaan tersebut dan akan menyebabkan harga saham perusahaan tersebut juga naik.

Pasar modal menyediakan informasi yang dipublikasikan untuk kepentingan para pelaku pasar modal (investor), yaitu dapat berupa informasi historical price, publikasi laporan keuangan perusahaan, informasi yang ada di laporan tahunan, dan kejadian-kejadian dalam perusahaan (Aulianisa, 2013).

Sebagai Negara dengan penduduk mayoritas muslim terbesar di dunia, pasar modal syariah di Indonesia mengalami perkembangan yang positif seiring dengan perkembangan industri syariah lainnya seperti perbankan, asuransi, reksadana dan lain-lainnya. Yang kemudian pada tahun 2000 Bursa Efek Indonesia (BEI) mengeluarkan indeks saham syariah untuk pertama kalinya yaitu Jakarta Islamic Index (JII). Indeks ini merupakan hasil dari kerjasama antara BEI dengan Danareksa Investment Management. Indeks ini merupakan indeks yang mengakomodasikan syariat investasi dalam Islam atau indeks yang berdasarkan syariat Islam (Darmadji dan Fakhruddin, 2001). Indeks harga saham merupakan indikator utama yang menggambarkan pergerakan harga saham (Umam, 2013).

Pada penelitian-penelitian sebelumnya, pengambilan sampel dilakukan pada perusahaan yang terdaftar di dalam indeks-indeks Bursa Efek Indonesia dengan mengkhususkan pada satu bidang sektor. Sedangkan, dalam penelitian ini penulis mengambil obyek saham syariah pada perusahaan yang berbasis syariah dalam kelompok Jakarta Islamic Index (JII) dikarenakan selain sebagai indeks saham syariah yang pertama kali diluncurkan di pasar modal Indonesia, konstituen JII juga hanya terdiri dari 30 saham syariah yang paling likuid tercatat di BEI. Review saham syariah yang menjadi konstituen JII dilakukan sebanyak dua kali dalam setahun, Mei dan November, mengikuti jadwal review DES dan OJK (ISS, 2019).

Dalam perkembangannya indeks JII selama kurun waktu 3 tahun terakhir selalu mengalami kenaikan. Sebagai gambaran nilai indeks dan kapitalisasi pasar dalam Jakarta Islamic Index (JII) serta jumlah saham syariah untuk tahun 2015-2017 nampak seperti dalam tabel berikut: 
Tabel 1. Perkembangan Kinerja Jakarta Islamic Index (JII) dan Perkembangan Jumlah Saham Syariah Tahun 2015-2017

\begin{tabular}{ccccc}
\hline \multirow{2}{*}{ Tahun } & \multirow{2}{*}{ Index } & $\begin{array}{c}\text { Kapitalisasi } \\
\text { Pasar }\end{array}$ & \multicolumn{2}{c}{ Jumlah Saham Syariah } \\
\cline { 3 - 5 } & & $1.737,29$ & Periode I & Periode II \\
\hline 2015 & 603,35 & $2.041,07$ & 331 & 331 \\
\hline 2016 & 694,13 & $2.288,02$ & 321 & 345 \\
\hline 2017 & 759,07 & & & 368 \\
\hline
\end{tabular}

Sumber: data diolah dari OJK

Pada periode akhir 2017 Jakarta Islamic Index (JII) ditutup pada level 759,09 poin atau meningkat sebesar 9,36\% dibandingkan pada periode 2016 sebesar 694,13 poin. Sementara itu, kapitalisasi saham yang tergabung dalam JII pada periode 2017 sebesar Rp 2.288,02 triliun atau 32,44\% dari total kapitalisasi pasar seluruh saham sebesar Rp 7.052,39 triliun. Selanjutnya, kapitalisasi pasar saham yang tergabung dalam JII pada akhir periode 2017 tersebut mengalami peningkatan sebesar 12,10\% jika dibandingkan kapitalisasi saham JII pada periode 2016 sebesar Rp 2.041,07 triliun (LPKSI, 2019). Selain dari kinerja JII, perkembangan pasar modal syariah di Indonesia juga dapat dilihat dari jumlah saham syariah yang diterbitkan. Dapat dilihat pada tabel di atas bahwa pada periode kedua tahun 2016 jumlah saham sebanyak 345 saham kemudian pada periode kedua tahun 2017 jumlah saham sebanyak 382 saham, hal ini menunjukkan bahwa jumlah saham syariah yang diterbitkan meningkat sebanyak 37 saham atau sekitar 10\% dari tahun 2016 (LPKSI, 2019).

Beberapa penelitian terdahulu, memiliki hasil yang berbeda dalam kaitannya pengujian pengaruh rasio keuangan terhadap harga saham. Zaki, Islahuddin dan Shabri di tahun 2017, menyebutkan bahwa Return on Asset (ROA) dan Debt to Equity Ratio (DER) secara simultan berpengaruh terhadap harga saham (Zaki et al., 2017). Sedangkan, pada penelitian Hasthoro dan Jepriyanto di tahun 2011, menyebutkan bahwa Debt to Equity Ratio (DER) tidak berpengaruh secara signifikan terhadap harga saham (Hasthoro dan Jepriyanto, 2011).

Pada penelitian Setiyawan dan Pardiman di tahun 2014, menyebutkan bahwa Current ratio (CR) bepengaruh positif dan signifikan terhadap harga saham dan Inventory turnover (ITO) berpengaruh negatif dan tidak signifikan terhadap harga saham (Setiyawan dan Pardiman, 2014). Penelitan serupa juga dilakukan oleh Rani dan Diantini di tahun 2015, yang hasilnya Current Ratio (CR) berpengaruh tetapi tidak signifikan terhadap harga saham (Rani dan Diantini, 2015). Sedangkan pada penelitian Suhadi di tahun 2009, menyebutkan bahwa Inventory turnover (ITO) mempunyai pengaruh yang signifikan positif terhadap harga saham (Suhadi, 2009).

Berdasarkan research gap di atas, maka perlu dilakukan penelitian lebih lanjut untuk mengetahui hasil penelitian manakah yang dapat didukung. Karena research gap di atas menunjukkan hasil yang tidak selalu konsisten. Sehingga penelitian ini masih menjadi permasalahan yang menarik untuk diteliti kembali. Hal inilah yang mendorong untuk diadakannya kembali penelitian mengenai faktor-faktor yang mempengaruhi perubahan harga saham ditinjau dari rasio keuangan perusahaan. Dimana faktor-faktor yang diduga mempengaruhi harga saham yaitu Return on Asset (ROA), Current Ratio (CR), Debt to Equity Ratio (DER), dan Inventory turnover (ITO). 


\section{TINJAUAN LITERATUR}

\section{Signaling Theory (Teori Sinyal)}

Menurut Brigham dan Houston, teori sinyal merupakan suatu tindakan yang diambil manajemen perusahaan yang memberi petunjuk bagi investor tentang bagaimana manajemen memandang prospek perusahaan (Brigham dan Houston, 2001). Teori sinyal (signaling theory) merupakan salah satu teori pilar dalam memahami manajemen keuangan. Secara umum, sinyal diartikan sebagai isyarat yang dilakukan oleh perusahaan (manajer) kepada pihak luar (investor). Sinyal tersebut dapat berwujud berbagai bentuk, baik yang secara langsung dapat diamati maupun yang harus dilakukan penelaahan lebih mendalam untuk dapat mengetahuinya. Apapun bentuk atau jenis dari sinyal yang dikeluarkan, semuanya dimaksudkan untuk menyiratkan sesuatu dengan harapan pasar atau pihak eksternal akan melakukan perubahan penilaian atas perusahaan. Artinya, sinyal yang dipilih harus mengandung kekuatan informasi (information content) untuk dapat merubah pihak eksternal perusahaan (Gumanti, 2009).

\section{Saham dan Harga Saham}

Saham (stock) merupakan bentuk penyertaan (kepemilikan) terhadap suatu perusahaan. Wujud kepemilikan (penyertaan) bahwa para pemegang saham memiliki seperangkat hak seperti hak bersuara dalam RUPS, residual claim dan sejenisnya. Kepemilikan saham pada suatu perusahaan ditunjukkan dengan sertifikat kepemilikan saham (Hadi, 2015). Sedangkan, saham syariah adalah sertifikat yang menunjukkan bukti kepemilikan perusahaan yang diterbitkan oleh emiten yang kegiatan usaha dan cara pengelolaannya tidak bertentangan dengan prinsip syariah.

Harga saham di pasar modal sangat ditentukan oleh kekuatan permintaan (demand) dan penawaran (supply). Semakin banyak investor yang membeli saham, semakin tinggi harga saham tersebut. Dalam perdagangan dan investasi, harga saham mengacu pada harga saham terkini dalam perdagangan saham. Indikator harga saham menggambarkan banyak hal yang terjadi saat ini diantara pembeli dan penjual. Indikator harga saham ini tidak hanya menggambarkan harga pasar, tetapi juga menggambarkan pihak yang saat ini sedang memegang kendali di pasar modal. Informasi terbaru yang masuk ke pasar modal akan menyebabkan investor membeli atau menjual saham. Hal ini menyebabkan terjadinya pergerakan harga.

\section{Rasio Profitabilitas}

Rasio Profitabilitas menggambarkan kemampuan perusahaan mendapatkan laba melalui semua kemampuan, dan sumber yang ada seperti kegiatan penjualan, kas, modal, jumlah karyawan, jumlah cabang, dan sebagainya (Harahap, 2013). Dalam penelitian ini rasio profitabilitas diwakili oleh Return on Assets (ROA). Return on Assets (ROA) merupakan rasio yang menunjukkan hasil (return) atas jumlah aktiva yang digunakan dalam perusahaan (Kasmir, 2010). ROA menghitung berapa banyak laba bersih setelah pajak dihasilkan oleh total aset yang dimiliki perusahaan (Husnan dan Pudjiastuti, 2015). 


\section{Rasio Likuiditas}

Rasio likuiditas mengukur kemampuan likuiditas jangka pendek perusahaan dengan melihat aktiva lancar perusahaan relatif terhadap hutang lancarnya (hutang dalam hal ini merupakan kewajiban perusahaan) (Hanafi dan Halim, 2005). Dalam penelitian ini rasio likuiditas diwakili oleh rasio lancar atau Current Ratio (CR). Current Ratio (CR) merupakan rasio untuk mengukur kemampuan perusahaan membayar kewajiban jangka pendek atau utang yang segera jatuh tempo pada saat ditagih secara keseluruhan (Kasmir, 2010).

\section{Rasio Solvabilitas}

Rasio solvabilitas menggambarkan kemampuan perusahaan dalam membayar kewajiban jangka panjangnya atau kewajiban-kewajiban apabila perusahaan dilikuidasi (Harahap, 2013). Dalam penelitian ini rasio solvabilitas diwakili oleh rasio utang terhadap modal atau Debt to Equity Ratio (DER). Rasio utang terhadap modal atau Debt to Equity Ratio (DER) merupakan rasio yang digunakan untuk mengukur besarnya proporsi utang terhadap modal (Hery, 2016).

\section{Rasio Aktivitas}

Rasio aktivitas (activity ratio), merupakan rasio yang digunakan untuk mengukur efektivitas perusahaan dalam menggunakan aktiva yang dimilikinya. Atau dapat pula dikatakan rasio ini digunakan untuk mengukur tingkat efisiensi pemanfaatan sumber daya perusahaan. Rasio aktivitas juga digunakan untuk menilai kemampuan perusahaan dalam melaksanakan aktivitas sehari-hari (Kasmir, 2010). Dalam penelitian ini rasio aktivitas diwakili oleh Inventory Turn Over (ITO). Inventory Turn Over (ITO) merupakan rasio di mana penjualan dibagi dengan aset. Sesuai dengan namanya, rasio ini menunjukkan berapa kali pos tersebut berputar sepanjang tahun (Brigham dan Houston, 2010).

\section{Pengembangan Hipotesis}

\section{Hubungan Return on Asset dengan harga saham}

Pada penelitian yang dilakukan Jiwando (2014) menunjukkan bahwa ROA berpengaruh positif signifikan terhadap harga saham. Hal tersebut sejalan dengan penelitian (Suselo et al., 2015). Semakin tinggi rasio profitabilitas maka akan semakin baik produktifitas aset dalam memperoleh keuntungan bersih atau laba, dimana untuk selanjutnya akan meningkatkan daya tarik investor dalam mengambil keputusan investasi pada perusahaan tersebut, sehingga akan meningkatkan harga saham perusahaan. Sehingga hipotesisnya sebagai berikut:

\section{H1 : Return on Asset berpengaruh positif terhadap harga saham}

\section{Hubungan Current Ratio dengan harga saham}

Pada penelitian yang dilakukan Pratama dan Erawati (2014) menunjukkan bahwa CR secara parsial berpengaruh positif dan signifikan terhadap harga saham. Hal itu sejalan dengan penelitian yang dilakukan Ilham, Yuhelmi dan Dharma (2016) menunjukkan bahwa CR berpengaruh positif terhadap harga saham. 
Berdasarkan penelitian yang dilakukan Pratama dan Erawati (2014) menunjukkan bahwa CR secara parsial berpengaruh positif dan signifikan terhadap harga saham. Hal itu sejalan dengan penelitian yang dilakukan Ilham, dkk (2016). menunjukkan bahwa CR berpengaruh positif terhadap harga saham (Ilham et al., 2016). Semakin tinggi rasio, maka semakin besar kemampuan perusahaan untuk membayar kewajibannya. Sehingga hipotesisnya sebagai berikut:

H2 : Current Ratio berpengaruh positif terhadap harga saham

\section{Hubungan Debt to Equity Ratio dengan harga saham}

Pada penelitian yang dilakukan Widayanti dan Colline (2017) menunjukkan bahwa DER signifikan berpengaruh terhadap harga saham. Hal itu sejalan dengan penelitian yang dilakukan Amalia (2010). DER yang aman yaitu kurang dari 50\%, jadi semakin kecil akan semakin baik. Sehingga hipotesisnya sebagai berikut:

\section{H3 : Debt to Equity Ratioberpengaruh positif terhadap harga saham}

\section{Hubungan Inventory Turnover dengan harga saham}

Pada penelitian yang dilakukan Darmawan dan Astuti (2016) menunjukkan bahwa ITO berpengaruh signifikan positif terhadap harga. Penelitian tersebut sejalan dengan penelitian yang dilakukan Mudlofir (2017).

Apabila rasio ITO yang diperoleh tinggi, ini menunjukkan perusahaan bekerja secara efisien dan likuid persediaan semakin baik. Demikian pula apabila perputaran sediaan rendah berarti perusahaan bekerja secara tidak efisien atau tidak produktif dan banyak barang sediaan yang menumpuk. Hal ini akan mengakibatkan investasi dalam tingkat pengembalian rendah (Kasmir, 2016). Sehingga hipotesisnya sebagai berikut:

\section{H3 : Inventory Turnover berpengaruh positif terhadap harga saham}

\section{Kerangka Hipotesis}

Berdasarkan penjelasan yang telah dipaparkan pada bagian sebelumnya, maka kerangka hipotesis dalam penelitian ini dapat digambarkan sebagai berikut:

\section{Gambar 1. Kerangka Hipotesis}

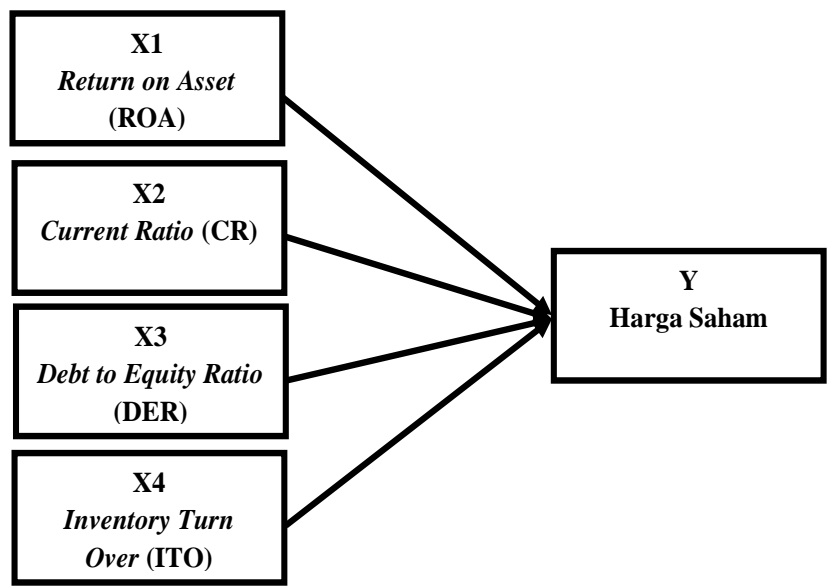




\section{METODE}

\section{Pengumpulan Data dan Pemilihan Sampel}

Jenis penelitian ini adalah penelitian kuantitatif dengan menggunakan data sekunder, berupa laporan keuangan tahunan perusahaan yang terdaftar di JII pada tahun 2015-2017 yang diperoleh melalui website Bursa Efek Indonesia melalui situs www.idx.co.id dan website masing-masing perusahaan. Populasi dalam penelitian ini adalah seluruh perusahaan yang sahamnya tercatat dalam Jakarta Islamic Index (JII) pada Bursa Efek Indonesia dengan kurun waktu tahun 2015-2017 yang berjumlah sebanyak 90 perusahaan. Sedangkan penarikan sampel penelitian ini dilakukan dengan menggunakan teknik purposive sampling, dimana kriteria pemilihan sampel adalah sebagai berikut:

a. Perusahaan yang tercatat dalam saham syariah yang tercantum dalam daftar perusahaan diJakarta Islamic Index (JII).

b. Memiliki posisi yang konsisten sebagai saham syariah yang tercatat pada Jakarta Islamic Index (JII) selama tahun 2015-2017.

c. Perusahaan telah menerbitkan annual report lengkap dan disajikan dalam mata uang rupiah untuk periode yang berakhir 31 Desember.

d. Laporan keuangan memiliki data yang lengkap untuk menghitung rasio keuangan yang digunakan dalam penelitian ini.

\section{Identifikasi dan Pengukuran Variabel}

Variabel terikat yang digunakan dalam penelitian ini adalah harga saham. Harga saham yang digunakan adalah harga saham tahunan yang diambil dari closing price setiap akhir tahun selama periode 2015-2017 yang dipublikasikan dalam laman resmi Bursa Efek Indonesia dan annual report perusahaan. Ukuran variabel harga saham adalah dalam bentuk rupiah.

Variabel bebas dalam penelitian ini meliputi:

a. Return On Asset (ROA). Rasio ini digunakan untuk mengukur seberapa besar jumlah laba bersih yang akan dihasilkan dari setiap dana yang tertanam dalam total asset (Hery, 2016: 106).

$$
R O A=\frac{\text { lababersih }}{\text { totalaset }}
$$

b. Current Ratio (CR). Rasio ini digunakan untuk mengukur kemampuan perusahaan membayar kewajiban jangka pendek atau utang yang segera jatuh tempo (Kasmir, 2010: 111).

$$
C R=\frac{\text { asetlancar }}{\text { kewajibanlancar }}
$$

c. Debt to Equity Ratio (DER). Rasio ini digunakan untuk mengukur perbandingan antara total utang dengan ekuitas (Hery, 2016: 24).

$$
D E R=\frac{\text { totalutang }}{\text { totalmodal }}
$$


d. Inventory Turnover (ITO). Rasio ini digunakan untuk mengukur berapa kali dana yang tertanam dalam satu periode (Hery, 2016: 25).

$$
\text { ITO }=\frac{\text { hargapokokpenjualan }}{\text { rata }- \text { ratapersediaan }}
$$

\section{Analisis Data}

Analisis data yang digunakan dalam penelitian ini adalah model regresi linier berganda. Model regresi linier berganda ini digunkan untuk mengetahui pengaruh ROA, CR, DER, dan ITO terhadap harga saham. Alat yang digunakan untuk analisis dalam penelitian ini adalah SPSS for windows. Model persamaan regresi yang digunakan adalah sebagai berikut:

$$
\mathrm{Y}=\mathrm{a}+\mathrm{b} 1 \mathrm{X} 1+\mathrm{b} 2 \mathrm{X} 2+\mathrm{b} 3 \mathrm{X} 3+\mathrm{b} 4 \mathrm{X} 4+\mathrm{e}
$$

Dimana :

$$
\begin{aligned}
& \mathrm{Y}=\text { harga saham } \\
& \mathrm{a}=\text { konstanta } \\
& \mathrm{b} 1,2,3=\text { koefisien } \\
& \mathrm{X} 1=\text { Return on Asset } \\
& \mathrm{X} 2=\text { Current Ratio } \\
& \mathrm{X} 3=\text { Debt to Equity Ratio } \\
& \mathrm{X} 4=\text { Inventory Turn Over } \\
& \mathrm{e}=\text { residual }
\end{aligned}
$$

Uji hipotesis dengan melihat nilai signifikansi $\mathrm{t}$ digunakan untuk mengetahui pengaruh variabel independen terhadap variabel dependennya. Jika nilai signifikansi t lebih kecil dari derajat kepercayaan (5\%) maka pengaruh variabel independen terhadap variabel dependen adalah signifikan. Model yang baik dapat dilihat berdasarkan nilai adjusted $\mathrm{R}^{2}$, nilai $\mathrm{t}$ dan nilai $\mathrm{F}$ nya. Sebelum melakukan uji hipotesis dilakukan uji asumsi klasik terlebih dahulu untuk memenuhi syarat estimasi linier tidak bias. Uji asumsi klasik yang dilakukan terdiri dari uji normalitas, multikolinieritas, heterokedastisitas dan autokorelasi.

\section{HASIL DAN PEMBAHASAN}

\section{Karakteristik Sampel}

Penelitian ini menggunakan data sekunder yang diperoleh dari laporankeuangan perusahaan yang terdaftar di Bursa Efek Indonesia melalui website resmiBursa Efek Indonesia (www.idx.co.id). Pemilihan sampel menggunakanmetode purposive sampling. Berdasarkan metode tersebut diperoleh 42 perusahaan selama 3 tahun periode penelitian yakni dari 2015 sampai dengan 2017.

\section{Hasil Uji Asumsi Klasik}

Hasil output SPSS atas uji asumsi klasik disajikan sebagai berikut: 
Tabel 2. Ringkasan Hasil Uji Asumsi Klasik

\begin{tabular}{lll}
\hline Uji Asumsi Klasik & \multicolumn{2}{l}{ Keterangan } \\
\hline Uji Normalitas & & \\
Asymp. Sig & 0.37 & \\
\hline Uji Multikoleniaritas & ROA & 0.908 \\
Tolerance & CR & 0.749 \\
& DER & 0.715 \\
& ITO & 0.970 \\
& & \\
VIF & ROA & 1.101 \\
& CR & 1.336 \\
& DER & 1.399 \\
& ITO & 1.031 \\
\hline Uji Heteroskedastisitas & ROA & 0.065 \\
& CR & 0.481 \\
& DER & 0.587 \\
& ITO & 0.186 \\
\hline Uji Autokorelasi & DW 1.459 \\
& N 42 \\
& K 4 \\
& DL & 1.285 \\
& DU 1.888 \\
& \multicolumn{2}{c}{4} \\
& &
\end{tabular}

Sumber: Hasil data diolah, SPSS

Pada uji normalitas peneliti menggunakan uji statistik non-parametik Kolmogorov-Smirnov (K-S). Pada uji normalitas nilai signifikan uji Kolmogolov Smirnov sebesar 0.37 yang berarti bahwa $(0,37>0,05)$ hal menunjukkan bahwa data yang digunakan berdistribusi normal karena nilai signifikan lebih dari 0,05.

Pada uji multikolinieritas di atas menunjukkan bahwa nilai tolerance dari semua variabel bebas memiliki nilai lebih dari 0,10 dan nilai VIF dari semua variabel bebas memiliki nilai kurang dari 10. Jadi dapat disimpulkan bahwa tidak terjadi multikolinieritas antar variabel bebas dalam model regresi.

Hasil pengujian heteroskedastisitas dengan uji glejser menunjukkan bahwa variabel ROA, CR, DER danITO memiliki nilai signifikan lebih dari 0,05. Jadi dapat disimpulkan bahwa tidak terdapat heteroskedastisitas, karena nilai signifikan lebih dari 0,05 .

Hasil perhitungan Durbin-Watson (DW test) menunjukkan nilai DW sebesar 1,888. Nilai ini akan dibandingkan dengan nilai du dan dl pada tabel dengan menggunakan nilai signifikansi 5\% $(0,05)$, dengan jumlah sampel dalam penelitian ini yaitu 42 dan jumlah variabel independen $4(\mathrm{k}=4)$, maka diperoleh $\mathrm{dl}=1,285$ dan $\mathrm{du}=1,721$. Oleh karena nilai $\mathrm{du}<\mathrm{DW}<4$-du, dimana 4-du=4-1,721=2,279 $(1,721$ $<1,888<2,279)$, maka dapat disimpulkan bahwa tidak ada autokorelasi positif negatif. 


\section{Hasil Uji Regresi Linier Berganda}

Hasil pengujian diperoleh persamaan regresi untuk menganalisis pengaruh Return on Asset(ROA), Current Ratio (CR), Debt to Equity Ratio (DER), dan Inventory Turn Over (ITO) terhadap harga saham perusahaan yang listing di Jakarta Islamic Index periode 2015-2017 adalah sebagai berikut:

$Y=3223.005+101825.940 X_{1}-1665.206 X_{2}+573.649 X_{3}-53.535 X_{4}+e$

\section{Hasil Uji Hipotesis}

Hasil uji hipotesis disajikan dalam tabel berikut:

Tabel 3. Ringkasan Hasil Uji Hipotesis

\begin{tabular}{|c|c|c|}
\hline Analisis Data & & Keterangan \\
\hline $\begin{array}{l}\text { Uji Koefisien } \\
\text { (Adjusted } R^{2} \text { ) }\end{array}$ & Determinasi & 0.657 \\
\hline \multicolumn{3}{|c|}{ Uji Signifikasi Simultan F } \\
\hline $\mathrm{F}$ & & 20.622 \\
\hline Sig & & 0.000 \\
\hline
\end{tabular}

\begin{tabular}{llc}
\hline Uji Signifikansi Parsial (Uji-T) & & \\
Koefisien kesalahan & ROA & 0.736 \\
standar & CR & -0.200 \\
& DER & 0.035 \\
& ITO & -0.121 \\
& & \\
$\mathrm{t}$ & ROA & 7.668 \\
& CR & -1.896 \\
& DER & 0.325 \\
& ITO & -1.307
\end{tabular}

Sig. $\quad$ ROA 0.000

CR $\quad 0.066$

DER $\quad 0.747$

ITO 0.199

Sumber: Hasil data diolah, SPSS

Hasil pengujian menunjukkan nilai adjusted $\mathrm{R}^{2}$ sebesar 0,657yang berarti bahwa variabel-variabel independen Return on Asset (ROA), Current Ratio (CR), Debt to Equity Ratio (DER), dan Inventory Turn Over (ITO)mampu menjelaskan variabel dependen (harga saham) sebesar 65\% sementara sisanya yaitu 35\% dijelaskan oleh variabel lain yang tidak dijelaskan dalam penelitian ini.

Hasil uji secara silmultan yang menggunakan tingkat signifikan sebesar 0,05 dan derajat kebebasan $\mathrm{df}=(\mathrm{n}-\mathrm{k}-1)=42-4-1=37$, maka diperoleh F-tabel sebesar 2,61. Hal ini menunjukkan bahwa nilai F-hitung lebih besar dari F-tabel $(20,622>2,61)$ dengan taraf signifikannya lebih kecil dari 0,05 $(0,000<0,05)$. Dengan demikian dapat diambil kesimpulan bahwa variabel Return on Asset (ROA), Current Ratio (CR), Debt to 
Equity Ratio (DER), dan Inventory Turn Over (ITO) secara bersama-sama berpengaruh signifikan terhadap harga saham perusahaan yang listing di Jakarta Islamic Index periode 2015-2017.

Berdasarkan uji $\mathrm{t}$ dapat disimpulkan bahwa hanya ROA yang berpengaruh terhadap harga saham, sedangkan CR, DER, dan ITO tidak berpengaruh terhadap harga saham.

\section{Pembahasan}

\section{Pengaruh Return on Asset (ROA) terhadap harga saham}

Berdasarkan Tabel 3 di atas, hasil uji t secara parsial yang menggunakan tingkat signifikan sebesar 0,05 dan dengan derajat kebebasan df $(\mathrm{N}-\mathrm{k}-1)=42-4-1=$ 37 diperoleh $\mathrm{t}$ tabel $=1,687$. Sedangkan hasil pengujian statistik terhadap Return on Asset (X1) menunjukkan t-hitung sebesar 7,668 dengan dengan taraf signifikansi 0,000. Sehingga nilai t-hitung $>$ t-tabel $(7,668>1,687)$ dan taraf signifikansinya lebih kecil dari $0,05(0,000<0,05)$. Dengan demikian dapat diambil kesimpulan bahwa terdapat pengaruh positif dan signifikan pada variabel Return on Asset (ROA) terhadap harga saham perusahaan yang listing di Jakarta Islamic Index periode 2015-2017.

Dari hasil penelitian menunjukkan bahwasemakin tinggi rasio ini maka akan semakin baik produktifitas aset dalam memperoleh keuntungan bersih atau laba, dimana untuk selanjutnya akan meningkatkan daya tarik investor dalam mengambil keputusan investasi pada perusahaan tersebut, sehingga akan meningkatkan harga saham perusahaan. Dan hal tersebut menyebabkan Return on Assets (ROA) berpengaruh terhadap harga saham.

Hasil penelitian ini sesuai dengan hasil penelitian yang dilakukan oleh Jiwando (2014) yang berjudul "Analisis Faktor Fundamental Terhadap Harga Saham Sektor Perbankan yang Go Public di Indeks Kompas 100", hasil penelitian menunjukkan bahwa ROA berpengaruh positif signifikan terhadap harga saham.

\section{Pengaruh Current Ratio (CR) terhadap harga saham}

Hasil pengujian statistik terhadap Current Ratio (X2) menunjukkan t-hitung sebesar -1,896 dengan dengan taraf signifikansi 0,066. Sehingga nilai t-hitung $<\mathrm{t}$-tabel $(-1,896<1,687)$ dan taraf signifikansinya lebih besar dari 0,05 $(0,066>0,05)$. Dengan demikian dapat diambil kesimpulan bahwa tidak terdapat pengaruh dan tidak terdapat perbedaan yang signifikan pada variabel Current Ratio (CR) terhadap harga saham perusahaan yang listing di Jakarta Islamic Index periode 2015-2017.

Hasil penelitian ini menunjukkan bahwa investor dalam melakukan investasi di saham perusahaan kurang mempertimbangkan besar kecilnya current ratio. Hal ini dikarenakan current ratio yang rendah menunjukkan adanya masalah dalam likuidasi, sebaliknya current ratio yang tinggi juga dianggap kurang bagus karena menunjukkan banyaknya dana menganggur yang pada akhirnya dapat mengurangi kemampuan perusahaan dimana alokasi dana menjadi tidak efektif (Gustmainar dan Mariani, 2018). Suatu perusahaan dengan CR yang tinggi belum menjamin bahwa utang perusahaan dapat dibayar sesuai dengan tanggal jatuh tempo dikarenakan distribusi aktiva lancar bisa tidak menguntungkan, misalnya jumlah persediaan yang relatif tinggi dan adanya saldo piutang tak tertagih yang besar (Gustmainar dan Mariani, 
2018). Sehingga hal tersebut menyebabkan Current Ratio (CR) tidak berpengaruh terhadap harga saham.

Hasil penelitian ini sesuai dengan hasil penelitian yang dilakukan oleh Gustmainar dan Mariani (2018) yang berjudul "Analisis Pengaruh Current Ratio, Debt To Equity Ratio, Gross Profit Margin, Retutn On Investment dan Earning Per Share Terhadap Harga Saham Pada Perusahaan LQ45 Yang Terdaftar Di BEI Tahun 20102016", hasil penelitian menunjukkan bahwa variabel CR tidak mempunyai pengaruh dan tidak signifikan terhadap harga saham.

\section{Pengaruh Debt to Equity Ratio (DER) terhadap harga saham}

Hasil pengujian statistik terhadap Debt to Equity Ratio (X3) menunjukkan thitung sebesar 0,325 dengan dengan taraf signifikansi 0,747. Sehingga nilai t-hitung < t-tabel $(0,325<1,687)$ dan taraf signifikansinya lebih besar dari 0,05 $(0,747>0,05)$. Dengan demikian dapat diambil kesimpulan bahwa tidak terdapat pengaruh dan tidak terdapat perbedaan yang signifikan pada variabel Debt To Equity Ratio (DER)terhadap harga saham perusahaan yang listing di Jakarta Islamic Index periode 2015-2017.

Dari hasil penelitian di atas, menunjukkan bahwa dalam realita pasar modal para investor dalam mengambil keputusan untuk menempatkan dana investasinya tidak begitu memperhitungkan baik buruknya kemampuan perusahaan dalam memenuhi kewajiban hutang jangka panjang atau tidak memperhitungkan risiko kerugian apabila terjadi kebangkrutan pada perusahaan tersebut karena apabila perusahaan mengalami kebangkrutan yang mendapat jaminan pengembalian dana adalah pihak kreditur bukan investor (Novitasari dan Herlambang, 2015). Di sisi lain, seorang analis juga harus hati-hati karena rasio hutang tidak menyajikan gambaran yang menyeluruh tentang risiko. Sehingga para investor yang memahami bahwa rasio hutang bukan gambaran risiko yang tepat bagi perusahaan mengabaikan nilai Debt to Equity Ratio (DER) dalam pengambilan keputusannya (Novitasari dan Herlambang, 2015). Hal tersebut menyebabkan Debt to Equity Ratio (DER) tidak berpengaruh terhadap harga saham.

Hasil penelitian ini sesuai dengan hasil penelitian yang dilakukan oleh Hasthoro dan Jepriyanto (2011) yang berjudul “Pengaruh Faktor-Faktor Fundamental Keuangan dan Risiko Sistematik terhadap Harga Saham Perusahaan yang Tergabung dalam Jakarta Islamic Index (JII)", hasil penelitian menunjukkan bahwa menyebutkan bahwa Debt to Equity Ratio (DER) tidak berpengaruh secara signifikan terhadap harga saham.

\section{Pengaruh Inventory Turn Over (ITO) terhadap harga saham}

Hasil pengujian statistik terhadap Inventory Turn Over (X4) menunjukkan thitung sebesar $-1,307$ dengan dengan taraf signifikansi 0,199. Sehingga nilai t-hitung $<$ t-tabel $(-1,307<1,687)$ dan taraf signifikansinya lebih besar dari 0,05 $(0,199>0,05)$. Dengan demikian dapat diambil kesimpulan bahwa tidak terdapat pengaruh dan tidak terdapat perbedaan yang signifikan pada variabel Inventory Turn Over (ITO) terhadap harga saham perusahaan yang listing di Jakarta Islamic Index periode 20152017. 
Hasil penelitian ini menunjukkan bahwa dalam realitanya di pasar modal investor cenderung tidak memperhatikan besar kecilnya nilai inventory turnover. Inventory turnover merupakan rasio manajemen aset yang menghitung seberapa sering persediaan mampu berputar dalam satu tahun. Jika inventory turnover semakin tinggi maka kemungkinan laba yang dihasilkan akan tinggi pula. Di sisi lain, apabila persediaan terlalu sering berputar juga bisa menyebabkan masalah likuiditas, bisa juga mengakibatkan ketidakmampuan perusahaan mencapai target penjualan karena minimnya persediaan pada perusahaan tersebut. Oleh karena itu, perputaran persediaan yang tinggi tidak selamanya baik, terkadang justru mengakibatkan masalah (Setiyawan dan Pardiman, 2014). Sehingga hal tersebut menyebabkan Inventory Turn Over (ITO) tidak berpengaruh terhadap harga saham.

Hasil penelitian ini sesuai dengan hasil penelitian yang dilakukan oleh Indra Setiyawan dan Pardiman (2014) yang berjudul "Pengaruh Current Ratio, Inventory Turnover, Time Interest Earned dan Return on Equity Terhadap Harga Saham Perusahaan Manufaktur Sektor Barang Konsumsi Yang Terdaftar di BEI", hasil penelitian menunjukkan bahwa variabel ITO berpengaruh negatif dan tidak signifikan terhadap harga saham.

\section{SIMPULAN}

Berdasarkan hasil analisis data tentang Analisis Harga Saham ditinjau dari Rasio Keuangan Perusahaan yang Listing di Jakarta Islamic Index (JII) Periode 20152017, dapat ditarik kesimpulan bahwa hanya variabel ROA yang berpengaruh signifikan terhadap harga saham. Sedangkan variabel CR, DER, dan ITO tidak berpengaruh signifikan terhadap harga saham.

\section{DAFTAR PUSTAKA}

Amalia, Henny Septiana. (2010). Analisis Pengaruh Earning Per Share, Return On Investment, dan Debt To Equity Ratio terhadap Harga Saham Perusahaan Farmasi di Bursa Efek Indonesia. Jurnal Manajemen dan Akuntansi, Vol. 11 No. 2 Oktober (2010).

Amanah, Raghila, Atmanto, Dwi dan Azizah, Devi Farah. (2014). Pengaruh RasioLikuiditas dan Rasio Profitabilitas terhadap Harga Saham (Studi pada Perusahaan Indeks LQ45 Periode 2008-2012). Jurnal Administrasi Bisnis, Vol. 12 No. 1 Juli (2014).

Aulianisa, Fitri. (2013). Pengaruh Faktor Fundamental dan Resikosistematik Terhadap Harga Saham di Pasar Modal Syariah (Studi Empiris JII di BEI Tahun 20072010). Jurnal Ekonomi Islam, Vol. 7 No. 1 Juli (2013).

Brigham, Eugene F. dan Houston, Joel F. (2010). Dasar-Dasar Manajemen Keuangan. Jakarta: Salemba Empat.

Brigham, Eugene F. dan Houston, Joel F. (2001). Manajemen Keuangan. Jakarta: Erlangga. 
Bursa Efek Indonesia. (2019). Indeks Saham Syariah. Diakses dari https://www.idx.co.id/idx-syariah/indeks saham-syariah.

Darmadji, Tjiptono dan Fakhruddin, Hendy M. (2001). Pasar Modal di Indonesia. Jakarta: Salemba Empat.

Darmawan, Rachmad dan Astuti, Desti Sri. (2016). Pengaruh Return On Asset dan Inventory Turnover terhadap Harga Saham. Journal of Management Studies, Vol. 3 No. 3 .

Deitiana, Tita. (2013). Pengaruh Current Ratio, Return On Equity dan Total Asset Turn Over terhadap Dividend Payout Ratio dan Implikasi pada Harga Saham Perusahaan LQ45. Jurnal Bisnis dan Akuntansi, Vol. 15 No. 1 Juni (2013).

Gumanti, Tatang A. (2009). Teori Sinyal dalam Manajemen Keuangan. Research Gate. https://www.researchgate.net/publication/265652260_Teori_Sinyal_Dalam_ Manajemen_Keuangan.

Gustmainar, Jojor, dan Mariani. (2018). Analisis Pengaruh Current Ratio, Debt To Equity Ratio, Gross Profit Margin, Retutn On Investment dan Earning Per Share Terhadap Harga Saham Pada Perusahaan LQ45 Yang Terdaftar Di BEI Tahun 2010-2016. BILANCIA, Vol. 2 No. 2 Desember (2018).

Hadi, Nor. (2015). Pasar Modal. Yogyakarta: Graha Ilmu.

Halim, Abdul. (2005). Analisis Investasi. Jakarta: Salemba Empat.

Hanafi, Mamduh, dan Halim, Abdul. (2005). Analisis Laporan Keuangan. Yogyakarta: AMP-YKPN.

Harahap, Sofyan Syafri. (2013). Analisis Kritis Atas Laporan Keuangan. Jakarta: Rajawali Pers.

Hasthoro, Handoko A. dan Jepriyanto, Endra. (2011). Pengaruh Faktor-Faktor Fundamental Keuangan dan Risiko Sistematik terhadap Harga Saham Perusahaan yang Tergabung dalam Jakarta Islamic Index (JII). Jurnal Bisnis dan Ekonomi, Vol. 2 No. 1 Juni (2011).

Hery. (2016). Financial Ratio For Business. Jakarta: Grasindo.

Husnan, Suad, dan Pudjiastuti, Enny. (2015). Dasar-Dasar Manajemen Keuangan. Yogyakarta: UPP STIM YKPN. 
Ilham, Muji, Yuhelmi dan Dharma, Surya. (2016). Pengaruh Kinerja Keuangan terhadap Harga Saham pada Perusahaan Hotel, Restoran Pariwisata yang Terdaftar di BEI Tahun 2011-2014. Jurnal Fakultas Ekonomi, Vol. 9 No. 2.

Jiwando, Teguh. (2014). Analisis Faktor Fundamental terhadap Harga Saham Sektor Perbankan yang Go Public di Indeks Kompas 100. Jurnal Ilmu Manajemen, Vol. 2 No. 3 Juli (2014).

Kasmir. (2016). Analisis Laporan Keuangan. Jakarta: Rajawali Pers.

Kasmir. (2010). Pengantar Manjaemen Keuangan. Jakarta: Kencana.

Meythi, Tan Kwang En dan Rusli, Linda. (2011). Pengaruh Likuiditas dan Profitabilitas terhadap Harga Saham Perusahaan Manufaktur yang Terdaftar di Bursa Efek Indonesia. Jurnal Bisnis Manajemen dan Ekonomi, Vol. 10 No. 2 Mei (2011).

Mudlofir. (2017). Pengaruh ROA, ROE, Inflasi, DER dan Inventory Turnover terhadap Harga Saham pada Perusahaan Otomotif yang Terdaftar di BEI Periode 2008-2013. Journal Of Accounting, Vol. 3 No. 3.

Muslich, Mohamad. (2003). Manajemen Keuangan Modern. Jakarta: Bumi Aksara.

Najmudin. (2011). Manajemen Keuangan dan Aktualisasi Syar'iyyah Modern. Yogyakarta: Andi.

Novitasari, Puput dan Herlambang, Leo. (2015). Pengaruh Current Ratio, Total Assets Turnover, Debt To Equity Ratio, dan Return On Equity terhadap Harga Saham pada Perusahaan yang Terdaftar di JII Periode 2009-2013. JESTT, Vol. 2 No. 4 April (2015).

Otoritas Jasa Keuangan. (2017). Laporan Perkembangan Keuangan Syariah Indonesia Tahun 2017. https://www.ojk.go.id/id/berita-dankegiatan/publikasi/Pages/Laporan-Perkembangan-Keuangan-Syariah$\underline{\text { 2017.aspx }}$

Pratama, Aditya, dan Erawati, Teguh. (2014). Pengaruh Current Ratio, Debt To Equity Ratio, Return On Equity, Net Profit Margin dan Earning Per Share. Jurnal Akuntansi, Vol. 2 No. 1 Juni (2014).

Rani, Kadek Sita, dan Diantini, Ni Nyoman Ayu. (2015). Pengaruh Kinerja Keuangan Perusahaan terhadap Harga Saham dalam Indeks LQ45 di BEI. E-Jurnal Manajemen Unud, Vol. 4 No. 6.

Raprayogha, Rusdi Rusnawati dan Abbas, Djamila. (2017). Pengaruh Kinerja Keuangan terhadap Harga Saham pada Sektor Industri Barang Konsumsi 
yang Tercatat di Jakarta Islamic Index (JII). Jurnal Manajemen Ide dan Inspirasi, Vol. 4 No. 1 Juni (2017).

Setiyawan, Indra dan Pardiman. (2014). Pengaruh Current Ratio, Inventory Turnover, Time Interest Earned dan Return On Equity terhadap Harga Saham pada Perusahaan Manufaktur Sektor Barang Konsumsi yang Terdaftar di BEI Periode 2009-2012. Jurnal Nominal, Vol. 3 No. 2.

Suhadi, Dady. (2009). Pengaruh Rasio Aktivitas, Rasio Profitabilitas, Rasio Leverage dan Rasio Penilaian terhadap Harga Saham Perusahaan Food and Beverage. Jurnal Informasi, Perpajakan, Akuntansi dan Keuangan Publik, Vol. 4 No. 1 Januari (2009).

Sulistyastuti, Dyah Ratih. (2002). Saham dan Obligasi. Yogyakarta: Penerbit UAJY.

Suselo, Dedi A. D. dan Indrawati, Nur Khusniyah. 2015. Pengaruh Variabel Fundamental dan Makro Ekonomi terhadap Harga Saham (Studi pada Perusahaan yang Masuk dalam Indeks LQ45). Jurnal Aplikasi Manajemen (JAM), Vol. 13 No. 1 Januari (2015).

Umam, Khaerul. (2013). Pasar Modal Syariah. Bandung: Pustaka Setia.

Wardiyah, Mia Lasmi. (2017). Analisis Laporan Keuangan. Bandung: Pustaka Setia.

Widayanti, Rita, dan Colline, Fredella. (2017). Pengaruh Rasio Keuangan terhadap Harga Saham Perusahaan LQ45 Periode 2011-2015. Jurnal Bina Ekonomi, Vol. 21 No. 1.

Zaki, Muhammad, Islahuddin dan Shabri, M. (2017). Pengaruh Profitabilitas, Leverage Keuangan dan Ukuran Perusahaan terhadap Harga Saham (Studi pada Perusahaan Manufaktur yang Terdaftar di Bursa Efek Indonesia Periode 20052014). Jurnal Megister Akuntansi, Vol. 6 No. 2 Mei (2017).

Zuliarni, Sri. (2012). Pengaruh Kinerja Keuangan terhadap Harga Saham pada Perusahaan Minning and Minning Service di Bursa Efek Indonesia (BEI). Jurnal Aplikasi Bisnis, Vol. 3 No. 1 Oktober (2012). 